\title{
LATE- AND POST-ALPINE TECTONIC EVOLUTION OF THE SOUTHERN PART OF THE ATHOS PENINSULA, NORTHERN GREECE
}

\author{
Georgiadis G. A. ${ }^{1}$, Tranos M. D. ${ }^{1}$, and Mountrakis D. M. ${ }^{1}$ \\ ${ }^{1}$ Aristotle University of Thessaloniki, School of Geology, Department of Geology, 54124 \\ Thessaloniki,Greece,gggk@geo.auth.gr,tranos@geo,auth.gr,dmountra@geo.auth.gr
}

\begin{abstract}
The boundary between Internal Hellenides and the Hellenic hinterland is exposed in the southern part of the Athos peninsula as a NE-SW trending contact between the Serbomacedonian massif and the Circum-Rhodope Belt. The main tectonic features and deformation of the area during late- and post-alpine times have been investigated in order to understand better the late orogenic processes that led to the present arrangement of this boundary. The field study showed that the prevailing structures in the southern Athos peninsula are an asymmetric, SW-plunging, NWverging mega-scale antiform and a NE-SW striking left-lateral shear zone. These structures are the result of a transpressional deformation that initiated at least since the Eocene under ductile, syn-metamorphic (low-greenschist facies) conditions and progressively changed during the Oligocene-Early Miocene to brittle conditions with $E$-W striking reverse faults-thrusts and NNW-SSE striking right-lateral and NESW striking left-lateral strike-slip faults. This deformation waned in Middle Miocene changing to transtension with E-W striking, left-lateral strike-slip and NW-SE rightlateral oblique to normal faults. Since the Late Miocene an extensional regime dominates the area with the least principal stress axis $\left(\sigma_{3}\right)$ orientated NE-SW during Late Miocene - Pliocene and N-S from Early Pleistocene-present.
\end{abstract}

Key words: Circum-Rhodope Belt, hinterland, collision, transpression, faulting.

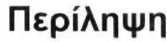

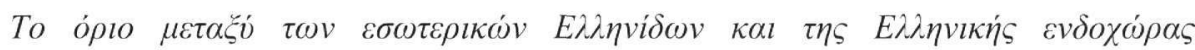

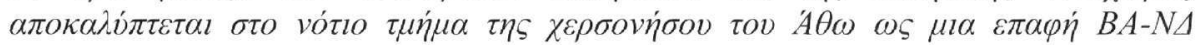

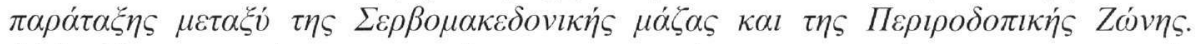

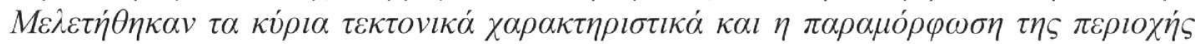

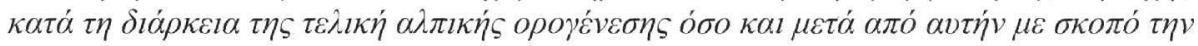

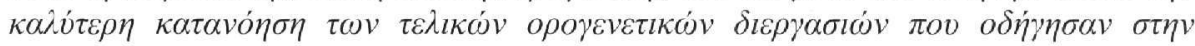

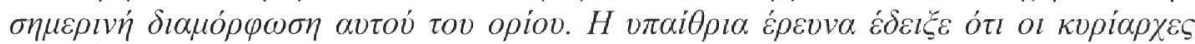

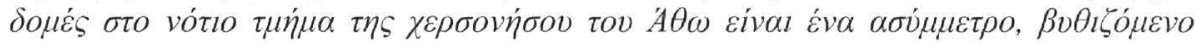

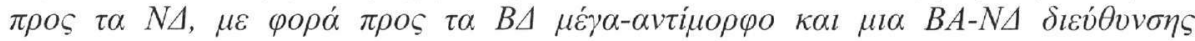

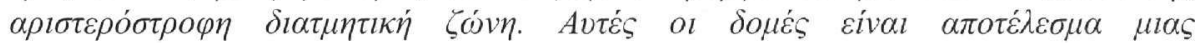

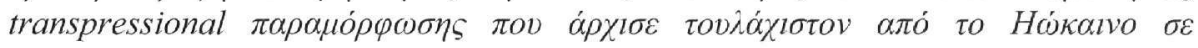

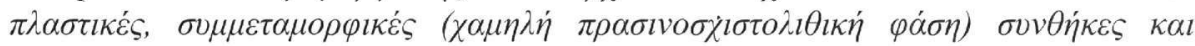

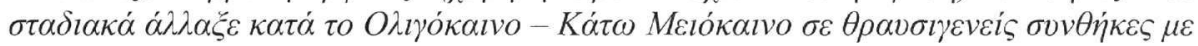




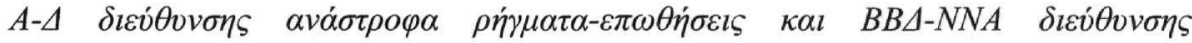

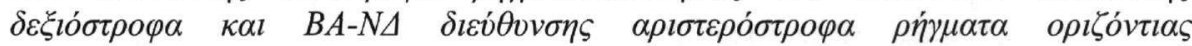

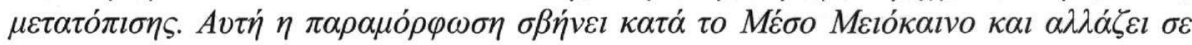
transtension $\mu \varepsilon A-\triangle \delta \imath \varepsilon v \dot{\theta v v \sigma \eta \varsigma ~ \alpha \rho \imath \sigma \tau \rho \rho ́ \sigma \tau \rho o \varphi \alpha ~ \rho \eta ́ \gamma \mu \alpha \tau \alpha ~ o \rho l \zeta o ́ v \tau \imath \alpha \varsigma ~ \mu \varepsilon \tau \alpha \tau o ́ \pi ı \sigma \eta \varsigma ~ \kappa \alpha l ~}$

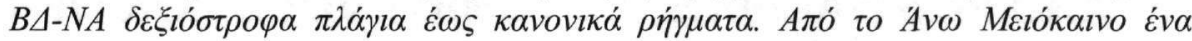

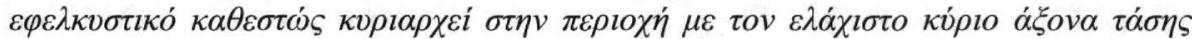

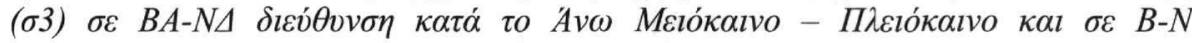

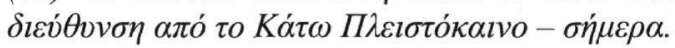

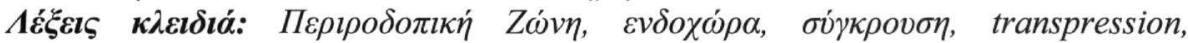

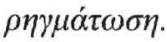

\section{Introduction}

In the Hellenic orogen, the Internal Hellenides are delimited to the east by the Serbomacedonian and Rhodope Massifs that constitute the hinterland of the orogen (Fig. 1). Specifically, this boundary in the area of the former Yugoslavia and Central Macedonia is located between the Serbomacedonian Massif to the East and the Circum-Rhodope Belt to the West and shows a constant NNW-SSE trend. This boundary has been interpreted as a rightlateral transpressional fold-and-thrust belt, the Circum Rhodope Thrust System (CRTS), formed during late collisional deformation (Tranos et al. 1999). The boundary at the SE extremity of the Chalkidiki peninsula

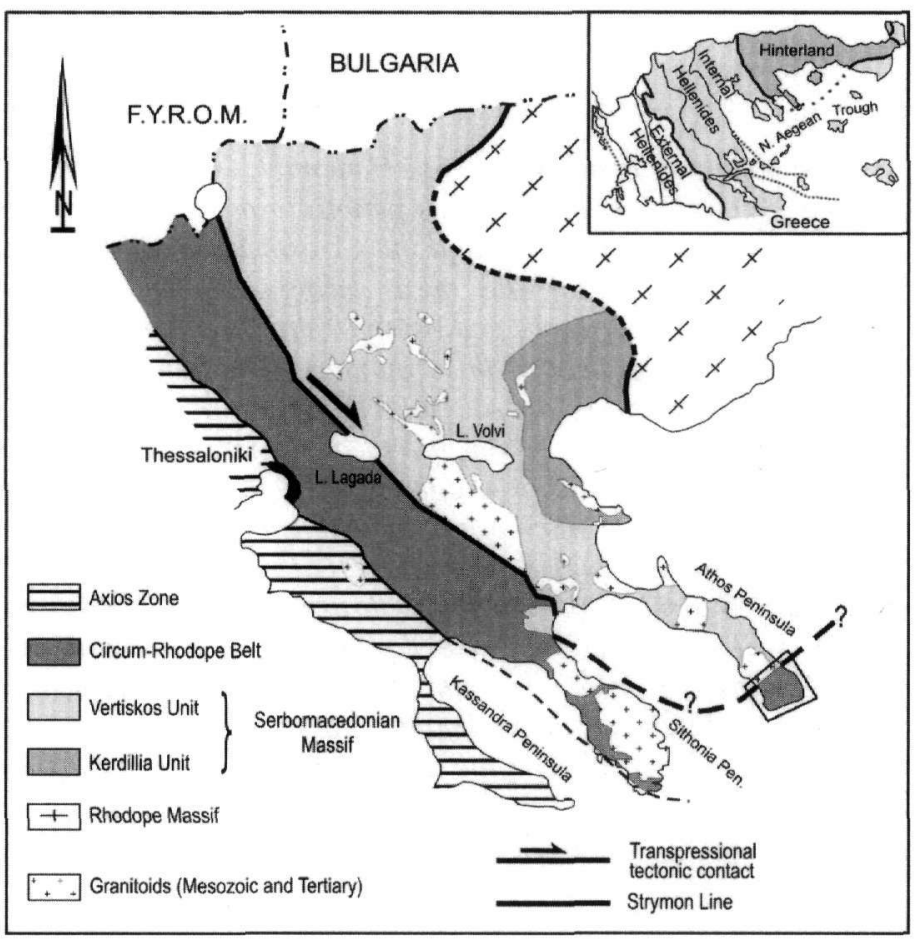

Figure 1 - Geotectonic map of central Macedonia-Chalkidiki peninsula

makes an abrupt change in trend from NNW-SSE to NE-SW. Because of the sea and the limited study of the area our understanding of this trend change is insufficient. In the southern part of the Athos peninsula, apart from basic geological mapping at 1:100.000 and 1:50.000 scales by Kockel et al. (1977) and Kockel and Mollat (1978) there has been no systematic study of the area and this trend change. As a result, the current view of the geology of the area and the boundary between the internal Hellenides and hinterland is that contained in their work.

This paper examines the geology and structural evolution of the southern part of the Athos peninsula, which is the only place where the NE-SW trend of the boundary between CircumRhodope Belt and the hinterland can be studied. Thus studying this boundary's trend change contributes to the better understanding of the deformation and the orogenic processes in this part of the Hellenic orogen. In particular, the geometry and kinematics of the ductile and brittle structures 
of the area have been studied and integrated with the existing views which suggest a left-lateral transpressional deformation for the region during Tertiary time.

\section{Geological setting}

The Serbomacedonian Massif (Fig. 1) consists of Paleozoic or older crystalline rocks that are grouped into the upper Vertiskos Unit and the lower Kerdillion Unit (Kockel et al. 1977) that consist of migmatites, biotite gneisses, marble horizons, two-mica gneiss and amphibolites. Towards the East, the Serbomacedonian Massif tectonically overlies the Rhodope Massif along the 'Strymon Line' that was considered as a Tertiary thrust fault by Kockel et al. (1977), but recent study has shown it to be a low-angle extensional detachment by Dinter and Royden (1993) and by Kilias et al. (1999).

The Circum-Rhodope Belt follows the NNW-SSE trend of the Serbomacedonian Massif (Fig. 1) and consists of Upper Paleozoic and Mesozoic meta-sedimentary rocks which have been grouped into the following three units (Kauffmann et al. 1976, Kockel et al. 1977) that are from East to West:

- the Deve Koran - Doubia Unit with Upper Paleozoic volcanosedimentary rocks and neritic Triassic carbonate rocks,

- the Melissochori - Cholomon Unit with Triassic pelagic carbonate and flysch metasediments of Middle Jurassic age, and

- the Aspri Vrisi - Chortiatis Unit with Permo-Triassic clastic rocks and Triassic neritic carbonate rocks in its lower part, and Lower-Middle Jurassic deep-sea sediments and ophiolites in its upper part. From these magmatic rocks the most characteristic rock types are those of mainly quartz-dioritic composition (Sapountzis 1969) that were metamorphosed to greenstones, green-gneisses and green-schists and make up the Chortiatis Magmatic Suite (Kockel et al. 1977). The intrusion of these magmatic rocks was attributed to the development of a volcanic arc in the area during the Middle Jurassic (Mussalam and Jung 1986).

The rocks of mainly the Serbomacedonian Massif, and the rocks of the Circum-Rhodope Belt were intruded by granitoids (Fig. 1) in Mesozoic to Tertiary times (Kockel et al. 1977, De Wet et al. 1989, Christofides et al. 1990).

A main orogenic phase that occurred in Middle-Late Jurassic time and affected the hinterland and the Internal Hellenides is attributed to the collision of the Cimmerian continent with Eurasia (Mountrakis 2002). In addition, the region was subjected to the Tertiary alpine orogenic phase that caused the final configuration of the whole Hellenic orogen and which is characterised by NW-SE trends and SW vergence (Dinaro-Hellenic orogenic fabric).

The first orogenic event was associated with an amphibolite facies metamorphism in the Serbomacedonian Massif and a greenschist facies metamorphism in the Circum-Rhodope Belt, followed by a retrograde low-grade greenschist facies metamorphism (Kockel et al. 1977; Dixon and Dimitriadis 1984, Vergely 1984, Chatzidimitriadis et al. 1985, Papadopoulos and Kilias 1985, Sakellariou 1989).

The Tertiary orogenic phase was associated with open, E-W trending, asymmetric folds and reverse-faults with south vergence (Sakellariou 1993). A similar NNW-SSE contraction associated with ESE-WSW trending folds, NNW-SSE and NE-SW trending shear zones and E-W trending thrusts faults deformed the Eocene Sithonia granitoid (Tranos et al. 1993).

The study of the post-metamorphic structures along the western boundary of the Serbomacedonian Massif (Tranos et al. 1999) and the Chalkidiki peninsula (Tranos 1998) suggests that the area underwent a transpressional deformation during the Latest Oligocene-Middle Miocene. This 
deformation was the result of a NNE-SSW contraction and its waning stage includes extensional faults that were related to an extension perpendicular to the NNE-SSW contraction (Tranos 1998). This deformational event is generally regional and related to the latest stages of the collision between the Apulian and Eurasian plates, since it has been recognized in SW Bulgaria (Tranos et al. 2006), Thrace (Koukouvelas and Doutsos 1990, Karfakis and Doutsos 1995) and the North Aegean Trough (Tranos 2004).

The deformation of central Macedonia since Late Miocene time is a continuous extension with the least principal stress axis $(\sigma 3)$ oriented NE-SW during Late Miocene - Pliocene and N-S from Lower Pleistocene to present (Mercier et al. 1989).

\section{Geology and structural elements of the area}

\subsection{Geology of the study area}

The southern part of the Athos peninsula (Fig. 2) exposes rocks that belong to the Aspro Vrisi Chortiatis Unit of the Circum-Rhodope Belt. More precisely, the central-northern part of the study area exposes greenstones, green-gneisses and greenschists of the Chortiatis Magmatic Suite, into which intercalations of schists and phyllites and few elongate tectonic slivers of serpentinized ultramafic rocks (ophiolites) are present. In addition, in the eastern part of the mapped area and within the Chortiatis Magmatic Suite, plagioclastic-microclinic gneisses have been mapped that alternate with the green-gneisses (Kockel et al. 1977). The central-southern part of the study area is covered by greyish-white and bluish-grey Triassic recrystallized limestones-marbles (Kauffmann et al. 1976) that form Mt. Athos. Here the Chortiatis Magmatic Suite is poorly exposed and forms a NE-SW trending narrow strip within the limestones-marbles.

At the NE edge of the study area, the Chortiatis Magmatic Suite is in contact with a NE-SW boundary with the crystalline rocks, i.e. gneisses of the Serbomacedonian Massif. However, the exposure of this boundary has been significantly obliterated, due to the emplacement of the Gregoriou granitoid along it. This granitoid is probably related to the Sithonia granitoid (Tranos et al. 1993) and has been recently dated as Eocene (Kontopoulou et al. submitted).

Post-alpine, Quaternary scree deposits of significant extent cover at places not only the rocks but their contacts as well.

\subsection{Ductile structures}

\subsubsection{Foliation}

The main foliation of the rocks of the Chortiatis Magmatic Suite is a $\mathrm{S}_{1}$ schistosity. This foliation trends generally NE-SW (Fig. 3a) and is parallel to the primary layering $\mathrm{S}_{0}$ of the rocks since it is almost parallel with the lithological boundaries in most of the mapped area. The minerals of the $\mathrm{S}_{1}$ foliation, such as chlorite, albite, actinolite, epidote and biotite, indicate a greenschist facies of metamorphism (Sapountzis 1969, Kockel et al. 1977).

At places, a second foliation $S_{2}$ is recognized affecting $S_{1}$ and forms a crenulation cleavage (Fig. 4a). The orientation of $S_{2}$ is constant throughout the study area dipping to SE (Fig. 3b) at moderate angles. $\mathrm{S}_{2}$ is associated with quartz re-crystallization and locally growth of muscovite and chlorite, indicating low-grade metamorphic conditions (greenschist facies metamorphism).

In the northern part of the study area a NNE-SSW to NE-SW trending mylonitic foliation $\left(\mathrm{S}_{\mathrm{m}}\right)$ affects the rocks of the Chortiatis Magmatic Suite forming in places with the $\mathrm{S}_{1}$ a vertical S-C fabric (Fig. 4b). This mylonitic schistosity is associated with minerals similar to those defining the $\mathrm{S}_{2}$ foliation and thus indicates similar metamorphic conditions. 


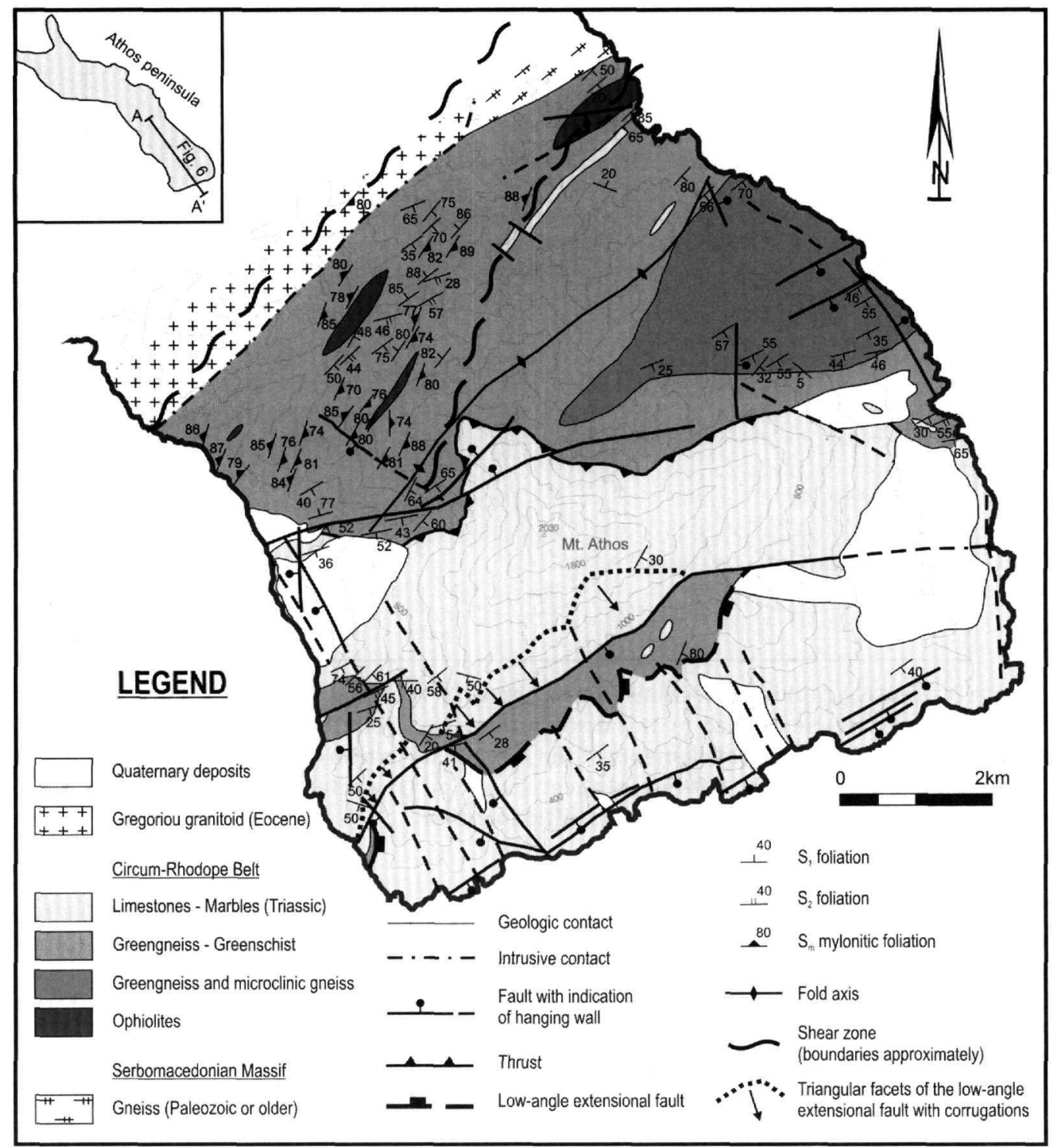

Figure 2 - Geologic map of the study area modified from Kockel et al. (1977)

\subsubsection{Folding}

The fieldwork carried out in the rocks of the Chortiatis Magmatic Suite indicates that the S1 foliation is folded at metre- to decimetre-scale, asymmetric, open-closed to overturned folds that plunge at gentle- to moderate angles $\left(\sim 30^{\circ}\right)$ mainly to the SSW (Figs 3c, 4c). The axial surface of the folds trends NE-SW and dips consistently towards SE at moderate angles. The fact that the $\mathrm{S}_{2}$ foliation is parallel to the axial surface forming crenulations in the $S_{1}$ foliation indicates that it is the axial planar schistosity of these folds. The mapping of $S_{1}$ and $S_{2}$ indicates that at a map-scale these folds are parasitic folds to a larger antiform of similar attitude and NW-vergence that dominates the southern area (Fig. 3d). In particular, the NNE- to NE-trending limb of the antiform is located north of Mt. Athos and dips at a high-angle to vertical. The other limb trends ENE and dips to the SE at a moderate angle and forms the main part of Mt. Athos and continues to until the southern edge of the peninsula. 


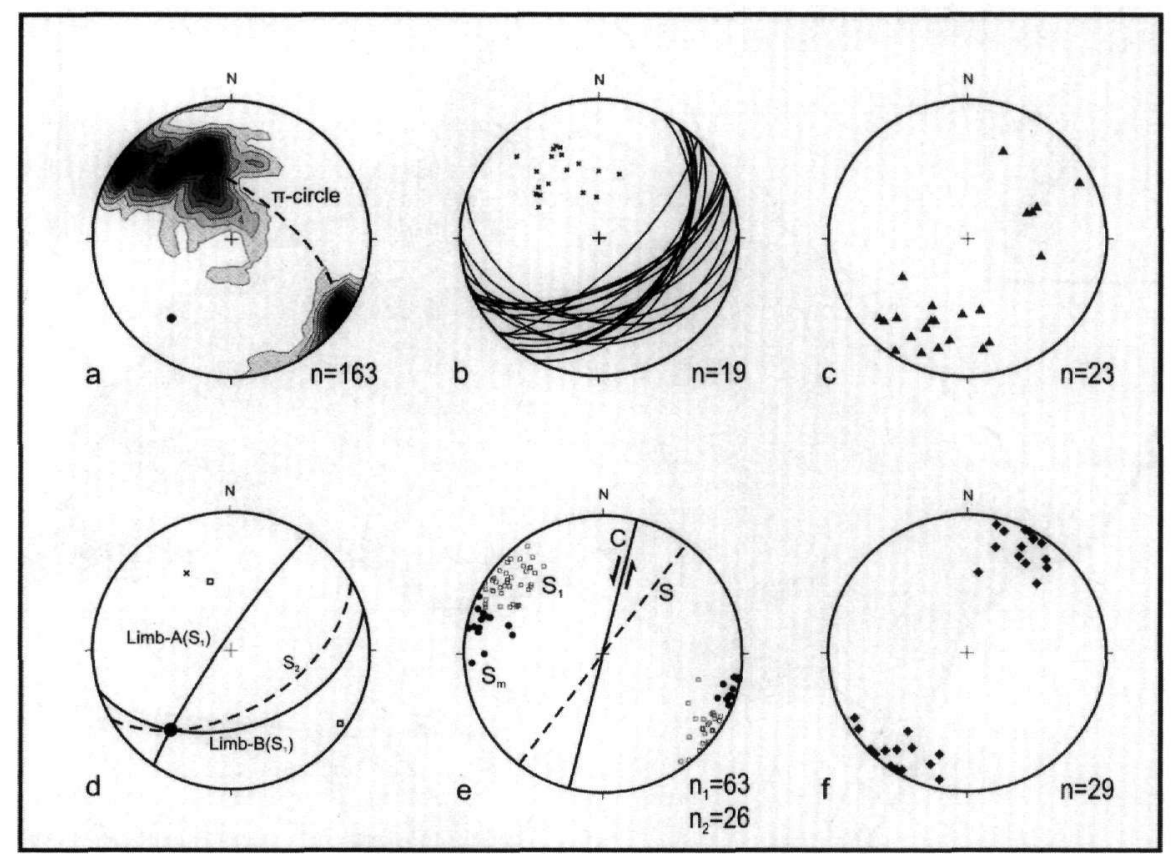

Figure 3 - Stereographic projections (lower hemisphere, equal area): (a) density of $S_{1}$, and the $\pi$-circle and $\pi$-pole defined by this distribution, (b) $S_{2}$ foliation, (c) axes of the mesoscale folds, (d) the main structural elements of the large scale antiform, (e) S-C fabric formed by $S_{1}$ and $S_{m}$ indicating the left-lateral shear zone, and (f) stretching lineation on the $S_{m}$ mylonitic foliation

\subsubsection{Shear zone}

The mylotitic foliation $\left(\mathrm{S}_{\mathrm{m}}\right)$ present in the central-northern part of the study area and in the rocks of the Chortiatis Magmatic Suite is the result of semi-ductile shearing that affected the $S_{1}$ foliation forming an S-C fabric (Fig. 3e). This mylonitic schistosity trends NNE-SSW (to NE-SW) and is (sub)vertical, in contrast to $\mathrm{S}_{1}$ that deviates from the vertical. The $\mathrm{S}-\mathrm{C}$ fabric is associated with a horizontal stretching lineation (Fig. 3f) and the S-C kinematics defines a left-lateral sense-of-shear (Fig. 4b). The varying intensity of the $S_{m}$ mylonitic foliation and consequently the S-C fabric at different locations implies that the shearing resulted by a heterogeneous shear zone. Due to this heterogeneity and the intense vegetation, the boundaries of the zone are defined approximately. The shear zone also affects the Eocene Gregoriou granitoid, since the later presents close to its contact with the Chortiatis Magmatic Suite a solid-state foliation parallel to $\mathrm{S}_{\mathrm{m}}$ (see Kockel et al. 1977). The approximate contacts of the mylonitic shear zone are shown in figure 2.

\subsection{Brittle structures}

Information concerning the geometry and kinematics of the faults in the map area were recorded and analyzed, and information about the cross-cutting relationship and overprinting criteria among the different faults has been also used to define their time succession in order to separate them into different faulting events. The separation of the faults was mainly based on their type, i.e. reverse, strike-slip and normal, and the use of the elaborated distribution of the $\mathrm{P}$ and $\mathrm{T}$-axes. The geometry and kinematics of these faults are the follow: 


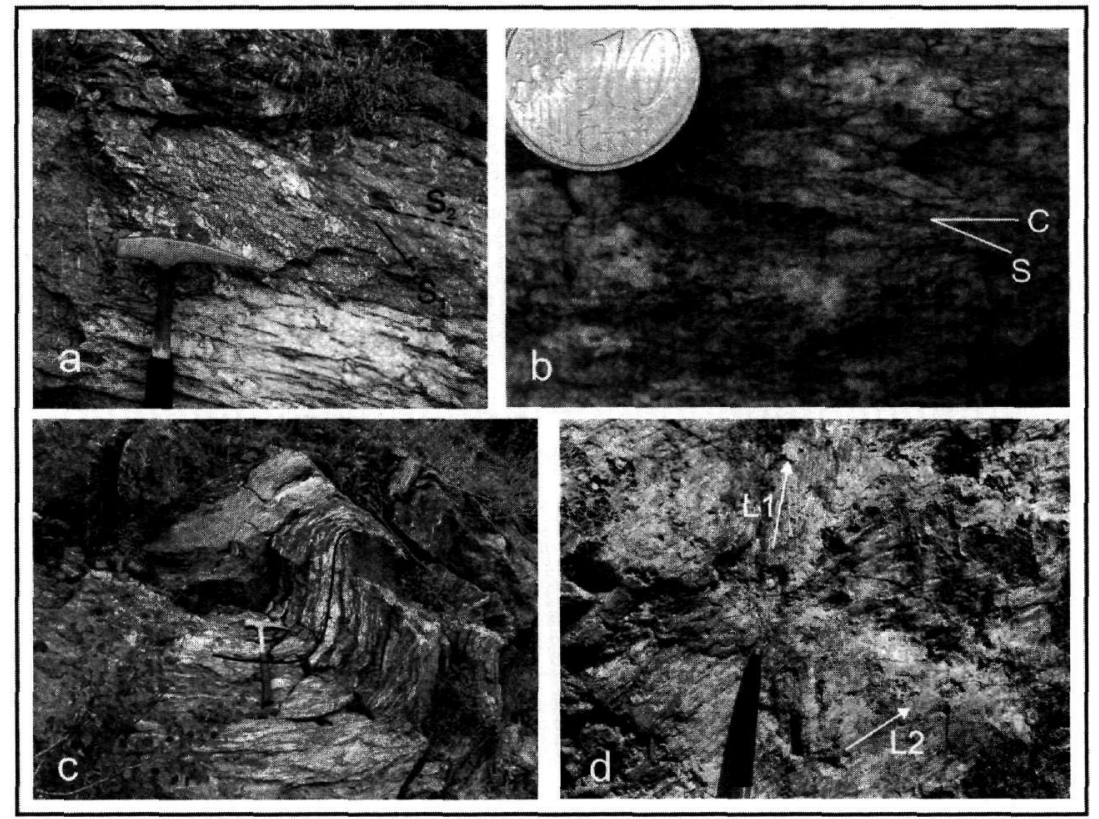

Figure 4 - Field photographs: (a) crenulation cleavage formed by the superpositon of the $S_{2}$

foliation on the $S_{1}$ (b) S-C mylonitic fabric indicating left-lateral shearing in the greengneisses, (c) asymmetric fold in the green-gneiss, (d) two generations of slickenlines (L1, L2) present on an E-W striking fault, with L2 (left-lateral strike-slip) overprinting L1 (reverse)

\subsubsection{Reverse faults}

The reverse faults strike $\sim \mathrm{E}-\mathrm{W}$ and dip at low angles to the south or at high angles to the north (Fig. 5a). Most of them exhibit a quartz coating where fiberlines and fibersteps are recognized defining N-S movements. On the northern slopes of Mt. Athos, N-directed thrusts have been found close to the contact of the Chortiatis Magmatic Suite with the overlying Triassic limestonesmarbles.

\subsubsection{Strike-slip faults}

The strike-slip faults of the area strike NNW-SSE, NE-SW and E-W and dip at high angles both to the north and south (Fig.5). They often exhibit Riedel structures and recrystallized quartz coating on which the formed microstructures (i.e. fiberlines and fibersteps) define the sense of movement. The majority of the NNW-SSE trending faults are right-lateral. In some cases, left-lateral strikeslip faults have been observed and these were attributed to local mechanical response of the rock. The NE-SW strike-slip faults are left-lateral and often they have been found close to the NNWSSE right-lateral faults. The E-W trending faults are left-lateral and on the fault surfaces the strikeslip slickenlines overprint the dip-slip reverse sense slickenlines (Fig. 4d).

\subsubsection{Normal faults}

The normal faults strike NW-SE and E-W, while sporadic N-S striking normal faults are also observed. The majority of the NW-SE striking faults are normal to oblique slip and in many cases they reactivated older right-lateral strike-slip faults. These faults cut the afore-mentioned reverse faults. The Mt. Athos is bounded by E-W and ENE-WSW striking faults that dip at high angles forming steep slopes (Fig. 2). The normal fault that diminishes the southern slopes of Mt. Athos affects a low-angle extensional fault dipping $20^{\circ} \mathrm{SSE}$ that parallels and modifies the contacts of the greenschists with the Triassic marbles forming similarly dipping, huge triangular facets with corrugations on the marble slopes of the footwall (Fig. 2). 


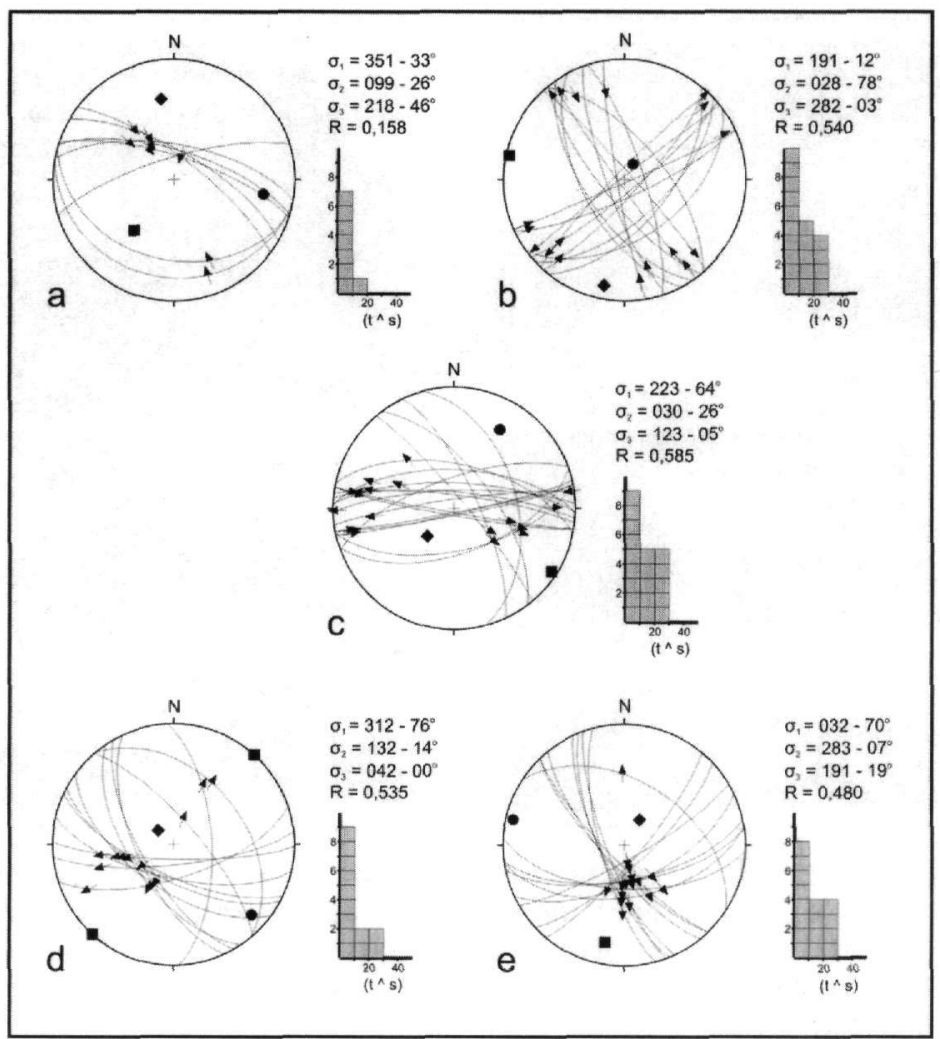

Figure 5 - Paleo-stress diagrams (lower hemisphere, equal area) and the deviation angle between the theoretical and real slip vector as calculated by the stress-inversion program described by Angelier (1990). (a) DA event -reverse faults, (b) DA event - strike-slip faults, (c) DB event - strike-slip and oblique extensional faults, (d) D1 event - normal faults, (e) D2 event - normal faults and oblique normal faults. $\sigma_{1}=$ diamond, $\sigma_{2}=$ circle, $\sigma_{3}=$ square

\subsubsection{Dynamic analysis-stress regimes}

Based on the discrimination of the faults into different types (reverse, strike-slip and normal), but also their temporal relations as established from fieldwork, the recorded faults were analyzed using the stress inversion program described by Angelier (1990). This program calculates the direction of the principal stress axes $\left(\sigma_{1}, \sigma_{2}, \sigma_{3}\right)$ and the ratio $\mathrm{R}=\left[\left(\sigma_{2}-\sigma_{3}\right) /\left(\sigma_{1}-\sigma_{3}\right)\right]$ of the stress ellipsoid. For an acceptable solution, we adopted the condition that the slip vector of the faults should not deviate more than $30^{\circ}$ from the theoretical one more than $90 \%$ of all the faults. The analysis elaborated five stress ellipsoids that define four deformational events. Due to the lack of stratigraphic criteria that would permit the dating of the deformational events, we correlated these events with the above field cross-cutting criteria and the previously reported regional deformational events.

DA - transpressional event: It is a pure-shear dominated transpressional event with the maximum stress axis $\left(\sigma_{1}\right)$ oriented N-S. It is determined from the reverse faults and NNW-SSE and NE-SW trending, strike-slip faults (Fig 5a, b). A tectonic event with similar fault geometry and kinematics was reported by Tranos (1998) for the Sithonia peninsula and for the Chalkidiki area, and also further to the north for the SW Bulgaria (Tranos et al. 2006) and is dated as Late Oligocene - Early Miocene. This event was also recognized farther to the East by reverse faults in the Thrace area by Koukouvelas and Doutsos (1990). During this event the minimum stress axis $\left(\sigma_{3}\right)$ varies between vertical and horizontal with a WNW trend with respect to the main faults, e.g. reverse or strike-slip faults at the different locations. 
DB - transtensional event: This event is defined by E-W striking left-lateral strike-slip faults and the NW-SE striking right-lateral oblique faults (Fig. 5c). It is characterized by a steeply plunging maximum stress axis $\left(\sigma_{1}\right)$ bearing SW and a horizontal minimum stress axis $\left(\sigma_{3}\right)$ bearing WNWESE. The elaborated intermediate stress axis $\left(\sigma_{2}\right)$ plunges gently to the NNE and is also compressive, indicating that contraction in this direction is similar to that in the previous DA event, but seems to wan during the DB event. The DB event was recognised by Tranos (1998) (DB and D1 events) and was dated as Early-Middle Miocene and it was also recognised more regionally (Tranos 2004, Tranos et al. 2006).

D1 - extensional event: The D1 event is characterized by NE-SW extension (Fig. 5d) and was dated in the Late Miocene - Pliocene by Pavlides and Kilias (1987), Mercier et al. (1989) and Tranos (1998). During this event, large NW-SE striking normal faults were activated and are considered to be the boundary faults to the NW-SE striking basins of the Northern Greece. Similar faults are recognised to form the NW-SE orientated Athos peninsula. It is important to mention that E-W-striking faults activated as left-lateral oblique faults during this event.

D2 - extensional event: The D2 event is characterized by N-S extension that leads to the activation of E-W-striking normal faults and NW-SE-striking left-lateral oblique faults (Fig. 5e). A large E-W-striking normal fault mapped along the north slopes of Mt. Athos is considered to be activated during this event and it is parallel to the large ENE-WSW striking faults that have been recognised offshore of the southern coastline of the peninsula and caused the subsidence along the southern slopes of the Athos peninsula (Papanikolaou et al. 2002). This event corresponds to the contemporary stress regime present over a wide region from Early Pleistocene to present and gives rise to the intense seismic activity of the area (Pavlides and Kilias 1987, Mercier et al. 1989, Tranos 1998, Mountrakis et al. 2006).

\section{Discussion - structural interpretation}

The geological structure of the southern part of the Athos peninsula is dominated by a SWplunging antiform with NNW-vergence and a left-lateral heterogeneous shear zone of NE-SW strike (Fig 6). The NE-SW trending mesoscale folds that are related to this antiform, although of different trend, were formed under similar low-grade metamorphic conditions (low greenschist facies) and have a similar style to the E-W trending (Sakellariou 1993) and ENE-WSW trending folds (Tranos et al. 1993) that have been reported for the Chalkidiki and Sithonia peninsula respectively. The NE-SW left-lateral shear zone is also associated with low-grade metamorphic conditions (low greenschist facies) and was formed by the same NNW-SSE to N-S contraction. These folds as well as shear zones and thrusts of similar kinematic symmetry have been attributed by the same authors to NNW-SSE to N-S contraction that has been dated in Eocene. Therefore, the folding and the shear zone of the southern part of Athos peninsula should be attributed to a common deformation event that took place at least since Eocene, since it affects the Gregoriou granitoid. The fact that this ductile deformation is of analogous kinematic symmetry and dynamic compatibility with the abovementioned DA brittle event allows us to consider that they both represent a single progressive DA event.

The NE-SW trend of the folds mapped in the southern part of the Athos peninsula that apparently differs from the ENE-WSW to E-W folds mentioned for the other adjacent regions could be explained by a transpressional deformation. More precisely, the folds could have initially formed as ENE-WSW folds normal to the NNW-SSE to N-S contraction and were progressively rotated anticlockwise to their present orientation. This explanation is supported by similar behaviour of folds formed during transpressional deformation as experimentally determined by Tikoff and Peterson (1998). That the NNW-SSE to N-S contraction determined by the left-lateral shear zone forms a high angle with the trend of the large antiform indicates that this event is a left-lateral 'pure shear dominated' transpression. 


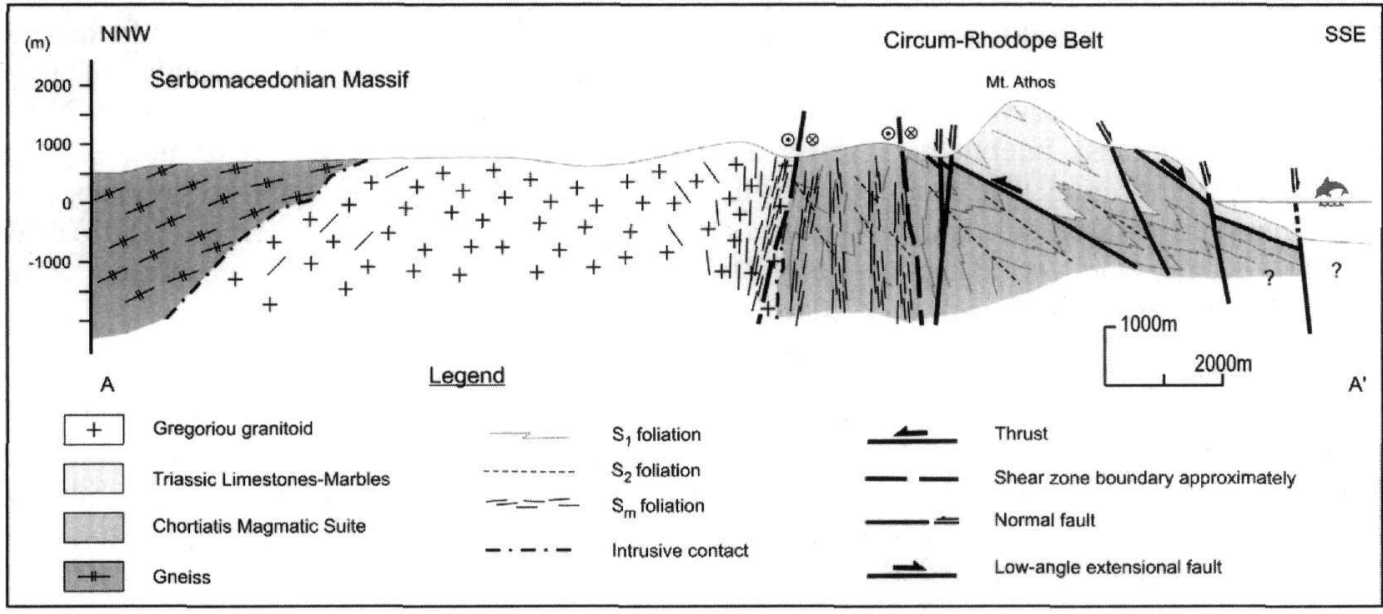

Figure 6 - Schematic cross section of the southern part of the Athos peninsula

The boundaries of the transpressional zone in the southern Athos peninsula defined by our fieldwork are oriented NE-SW, parallel to the boundary of the Serbomacedonian Massif and the Circum-Rhodope Belt and possibly may continue further to NE.

The DA event is a ductile 'pure-shear dominated' transpression that evolved during the Late Oligocene - Early Miocene in more brittle conditions activating reverse and strike-slip faults that also define a similar N-S contraction. This left-lateral transpression could be considered analogous to the NW-SE trending right-lateral transpression along the Circum Rhodope Thrust System (Tranos et al. 1999). The DA deformation changed to the DB transtension during the Early-Middle Miocene activating E-W-striking left-lateral strike-slip faults and NW-SE-striking oblique extensional faults that gave rise to a WNW-ESE extension and a NNE-SSW contraction. The activation of the SSE-dipping low-angle extensional fault mapped in the southern slope of Mt. Athos is attributed to the DB because its orientation and kinematics favours the NW-SE extension that characterises this event. Besides, similar low-angle extensional faults have also been reported for the Early-Middle Miocene in the wider area (Tranos 1998, Tranos et al. 2006).

Therefore, the studied area, and thus the boundary between the hinterland and the Internal Hellenides was progressively deformed under both ductile and brittle conditions by a transpressional deformation, which is dated as Tertiary and more precisely from at least the Eocene to Middle Miocene. This deformation is attributed to the main and late-orogenic collision between the Apulian - Eurasian plates.

The younger activation of the faults defines NE-SW and N-S extensional regimes that are postcollisional ones and related to the Hellenic subduction zone. These regimes fit well with the already reported extensional regimes since the Late Miocene (Pavlides and Kilias 1987, Mercier et al. 1989, Pavlides et al. 1990, Tranos 1998, Mountrakis et al. 2006). The uplift of the Athos peninsula is attributed to the NE-SW extension, whereas the final configuration of Mt. Athos is mainly attributed to the N-S extension.

\section{Acknowledgments}

Dr. Uwe Ring and Dr. Clark Burchfiel are thanked for their comments and suggestions.

\section{References}

Angelier, J., 1990. Inversion of field data in fault tectonics to obtain the regional stress. III. A new rapid direct inversion method by analytical means. Geophys. J. Int., 103, 363-376. 
Christofides, G., D’Amico, C., Del Moro, A., Eleftheriadis, G., and Kyriakopoulos, C., 1990. $\mathrm{Rb} / \mathrm{Sr}$ geochronology and geochemical characters of the Sithonia plutonic complex (Greece), Eur. J. Mineral., 2, 79-87.

Chatzidimitriadis, E., Kilias, A., and Staikopoulos, G., 1985. Nouvi aspetti petrologici e tettonici del massiccio Serbomacedonne e delle regioni adiacenti, della Grecia del Nortd, Boll. Soc. Geol. It., 104, 515-526.

De Wet, A. P., Miller, J. A., Bickle, M. J., and Chapman, H, J., 1989. Geology and geochronology of the Arnea, Sithonia and Ouranoupolis intrusions, Chalkidiki peninsula, northern Greece, Tectonophysics, 161, 65-79.

Dinter, D. A., and Royden, L., 1993. Late Cenozoic extension in northeastern Greece: Strymon Valley detachment system and the Rhodope metamorphic core complex, Geology, 21, 4548.

Dixon, J. E., and Dimitriadis, S., 1984. Metamorphosed ophiolitic rocks from the Serbomacedonian Massif, near Lake Volvi, Northeast Greece, The Geological Evolution of the Eastern Mediterranean. Geol. Soc. Lond., Spec. Publ., 17, 603-618.

Karfakis, J., and Doutsos, T., 1995. Late orogenic evolution of the Circum-Rhodope Belt, Greece, N. Jahrb. Geol. Paläont. Mh., 5, 305-319.

Kauffmann, G., Kockel, F., and Mollat, H., 1976. Notes on the stratigraphic and paleogeographic position of the Svoula Formation in the Innermost Zone of the Hellenides (Northern Greece), Bull. Soc. Geol. France, 7, t. XVIII, n 2. 225-230.

Kilias, A., Falalakis, G., and Mountrakis, D., 1999. Cretaceous-Tertiary structures and kinematics of the Serbomacedonian metamorphic rocks and their relation to the exhumation of the Hellenic hinterland (Macedonia, Greece), Int. Journ. Earth Sciences, 88, 513-531.

Kockel, F., Mollat, H., and Walther, H. W., 1977. Erlauterungen zur Geologischen Karte der Chalkidhiki und angrenzender Gebiete 1:100.000 (Nord-Griechenland). Bundesanstalt fur Geowisseschaften und Rohstoffe, Hannover, 119pp.

Kockel, F., and Mollat, H., 1978. Geologic map of Greece 1:50.000 scale, Athos sheet. Institute of Geology and Mineral Exploration, Athens.

Kontopoulou, D. Zananiri, I., Michard, A., Feinberg, H., Atzemoglou, A., Pozzi, J.-P., and Voidomatis, Ph., subm. Neogene tectonic rotations in the vicinity of the North Aegean Trough: New palaeomagnetic evidence from Athos and Samothraki (Greece), Bull. Geol. Soc. Greece.

Koukouvelas, I., and Doutsos, T., 1990. Tectonic stages along a traverse cross cutting the Rhodopian zone (Greece), Geol. Rundschau, 79, 3, 753-776.

Mercier, J.-L., Simeakis, K., Sorel, D., andVergely, P., 1989. Extensional tectonic regimes in the Aegean basins during the Cenozoic, Basin Research, 2, 49-71.

Mountrakis, D., 2002. Tectonic evolution of the Hellenic orogen. Geometry and kinematics of the deformation, Bull. Geol. Soc. Greece, vol. XXVIV, 2113-2126 (in Greek with English abstract).

Mountrakis, D., Tranos, M., Papazachos, C., Thomaidou, E., Karagianni, E., and Vamvakaris, D., 2006. Neotectonic and seismological data concerning major active faults, and the stress regimes of Northern Greece. In A. H. F. Robertson and D. Mountrakis (eds), Tectonic development of the Eastern Mediterranean region. Geol. Soc. Lond., Spec. Publ. 260, 649$670 \mathrm{pp}$. 
Mussalam, K., and Jung, D., 1986. Petrology and geotectonic significance of salic rocks preceding ophiolites in the Eastern Vardar Zone, Greece, Tschermaks Min. Petr. Mitt., 35, 217-242.

Papadopoulos, C., and Kilias, A., 1985. Alterbeziehungen zwischen Metamorphose und Deformation im zentralen Teil des Serbomazedonischen Massivs (Vertiskos Gebirge, NordGriechenland), Geol. Rundsch., 74, 77-85.

Papanikolaou, D., Alexandri, M., Nomikou, P., and Ballas, D., 2002. Morphotectonic structure of the western part of the North Aegean Basin based on swath bathymetry, Marine Geology, $190,465-492$.

Pavlides, S. B., and Kilias, A. A., 1987. Neotectonic and active faults along the Serbomacedonian zone (SE Chalkidiki, northern Greece), Ann. Tecton., 1, 97-104.

Pavlides, S., Mountrakis, D., Kilias, A., and Tranos, M., 1990. The role of strike-slip movements in extensional area of Northern Aegean, (Greece). A case of transtensional tectonics, Ann. Tecton., 4, 196-211.

Sakellariou, D., 1989. The geology of the Serbomacedonian massif in the northeastern Chalkidiki peninsula, North Greece. Deformation and metemorphism, $P h D$ thesis, Univ. Mainz, $177 \mathrm{pp}$.

Sakellariou, D., 1993. Tectonometamorphic evolution of the geotectonic units of the Chalkidiki peninsula, Bull. Geol. Soc. Greece, vol. XXVIII, 165-177.

Sapountzis, I., Petrography and geological setting of the greengneisses of Thessaloniki, $P h D$ thesis, Univ. Thessaloniki. (in Greek with English summary)

Tikoff, B., and Peterson, K., 1998. Physical experiments of transpressional folding, J. Struct. Geol, 20, 661-672.

Tranos, M. D., 1998. Contribution to the study of the neotectonic deformation in the area of Central Macedonia and North Aegean. PhD thesis, Univ. Thessaloniki (in Greek with English summary).

Tranos, M. D., 2004. Faulting of the Lemnos Island (northern Greece). In: A. A. Chatzipetros and S. B. Pavlides (eds), Proceedings of the $5^{\text {th }}$ International Symposium on Eastern Mediterranean Geology, vol. 1, 205-208pp.

Tranos, M. D., Kachev, V. N., and Mountrakis, D. M., 2006. Transtensional origin of the Simitli basin, SW Bulgaria. In: M. Sudar, M. Ercegovac and A. Grubić, Proceedings of the XVIII ${ }^{\text {th }}$ Congress of the Carpathian-Balkan Geological Association, 636-640.

Tranos, M. D., Kilias, A. A., and Mountrakis, D. M., 1993. Emplacement and deformation of the Sithonia granitoid pluton (Macedonia, Hellas), Bull. Geol. Soc. Greece, vol. XXVIII, 195210.

Tranos, M. D., Kilias, A. A., and Mountrakis, D. M., 1999. Geometry and kinematics of the Tertiary post-metamorphic Circum Rhodope Belt Thrust System (CRBTS), Northern Greece, Bull. Geol. Soc. Greece, vol. XXXIII, 5-16.

Vergely, P., 1984. Tectonique des ophiolites dans le Hellenides internes. Consequences sur l'evolution des regions Tethysiennes occidentales, $P h D$ thesis, University of Paris, Paris. 